\title{
ANAEMIA IN NEPHRITIS
}

BY

PATRICK MACARTHUR, M.B., Ch.B.

(From the Department of Paediatrics, University of Glasgow, and the Royal Hospital for Sick Children, Glasgow)

The intractable anaemia of nephritis has been extensively investigated in adults, but there has been little detailed study of the blood changes occurring in the nephritis of childhood, though at this age period complicating factors are less common than in adults. It is generally agreed that the anaemia of nephritis is not markedly hypochromic; some indeed consider that it is orthochromic, and in some cases a colour index even above unity has been recorded. Furthermore, it has never been conclusively shown in which type of the disease the anaemia is most in evidence.

Parsons and Ekola-Strolberg (1933) state that anaemia is common in chronic nephritis, but after an extensive investigation of the literature and from their personal observations they conclude that anaemia is almost always present in cases with azotaemia regardless of the pathological basis of the renal insufficiency. They further claim that there is a parallel between the degree of anaemia and the extent of the azotaemia. They agree with van Slyke (1930) that anaemia is as valuable a prognostic sign as azotaemia. Grawitz (1911) believed that hydraemia produced an apparent anaemia, but he only found it to be present when cardiac decompensation developed. Thursfield (1934) observed that acute nephritis with oedema was often accompanied by a marked anaemia, but considered that this was more apparent than real as it was in all probability due to oedema of the blood.

Ceconi (1905) was the first to suggest that the anaemia was aplastic and due to toxic action on the bone marrow. This hypothesis is the one most widely held at the present time. Wintrobe (1934) drew attention to the similarity of the blood picture in the anaemias of nephritis, marrow aplasia, and the anaemia which he found in the various inflammatory diseases. All were normocytic or microcytic, but in none was there a marked hypochromia. In his series of cases of nephritis the average red cell count was 3.58 millions per c.mm., the average haemoglobin 70 per cent. (Haldane), and the average packed cell volume 30 per cent. Murphy et al. (1934) state that in acute nephritis a red cell count below 3.5 millions per c.mm. implies progressive breakdown of renal function.

The changes that oedema causes in the concentration of red cells have also been the subject of several investigations. As already noted, Grawitz (1911) believed that the anaemia of nephritis was simply the result of a hydraemic plethora secondary to cardiac decompensation. Reference has also been made to Thursfield's opinion that oedema of the blood occurs in many cases of acute haemorrhagic nephritis in which there is general oedema. McClure and his co-workers (1933) made a detailed study of the red cell count of capillary blood 
in nephrotic oedema during its increasing, stationary and subsiding phases. They found that the red cell count, haemoglobin and packed cell volume all increased as the oedema advanced, decreased with stationary oedema and still further decreased when diuresis occurred and oedema lessened. They considered that these changes might be explained by movement of fluid from the blood to the tissues during the period of increasing oedema, whereas during lessening oedema fluid returned from the tissues to the blood and concluded that in the nephrotic syndrome the fault lies in the tissues rather than in failure of the kidneys to excrete water. Such an explanation cannot be considered conclusive without further facts being known, as it does not take into consideration the possibility that the increasing cell counts may be due partly to the expulsion of red cells from the blood depots of the body into the circulating blood as well as to subtraction of fluid from it.

Thus a survey of the literature shows that, whilst most workers agree that anaemia frequently occurs in nephritis, there is considerable difference of opinion regarding the type of nephritis in which anaemia is found, and the character of the anaemia when it does occur. In the present investigation an attempt has been made to gather fresh information on these two points.

\section{Method of investigation}

Duplicate red cell counts, using separate pipettes for each, were done at intervals of not more than a week on all cases. If the difference between the two counts was not more than 200,000 per c.mm. the average was taken to express the true count, but if the difference was greater than this, the results were discarded and the process repeated. Capillary blood was obtained by puncturing the lobe of the ear with a Hagedorn needle and venous blood was aspirated from a vein in the ante-cubital area with minimal venous stasis. Haemoglobin was estimated by Haldane's method at the same time as the red cell counts were made. White cell counts were done weekly and the average of duplicate counts was taken. At the first examination of each case, reticulocyte counts were made from preparations stained with brilliant cresyl blue, and these were repeated as circumstances suggested. At the same time films were stained with Leishman's stain and examined for abnormal cells. Serum protein was estimated by the dipping refractometer. The urinary volume and the patient's weight were measured daily. The degree of oedema was noted at the time of each count.

The packed cell volume was estimated by the haematocrit at intervals of approximately two weeks. About 6 c.c. of blood was withdrawn from an elbow vein with minimal venous stasis into a 10 c.c. haematocrit tube containing 2 c.c. neutral potassium oxalate solution to prevent coagulation. The blood was covered with a thin layer of liquid paraffin to prevent evaporation and centrifugalized at 3000 revolutions per minute for 30 minutes. In the earlier tests a solution of 1.6 per cent. neutral potassium oxalate was employed to prevent coagulation as recommended by Hooper et al. (1920). Later, in view of the criticism by Graff and Clarke (1931) of this method a 1.1 per cent. solution of neutral potassium oxalate was employed with more satisfactory results. From the red cell counts and the haematocrit readings the mean corpuscular volume was calculated according to the formula of Wintrobe (1934).

The effect of oedema on the accuracy of counts on capillary blood. When withdrawing blood by skin puncture in oedematous patients it is possible that there may be dilution of the blood by admixture with fluid from the oedematous 
tissues. In order to decide whether this was sufficient to invalidate counts made on capillary blood a series of red cell counts and haemoglobin estimations was done on blood obtained by skin puncture and on blood withdrawn from a vein. The venous blood was mixed with a little powdered oxalate in a glass tube and then carefully but thoroughly mixed immediately before the estimations were made. Eighty-three of these duplicate blood counts, capillary and venous, were done on thirteen subjects. Thirty-nine of the counts were done at a time when there was no oedema, as shown by the absence of pitting on pressure and puffiness of the face and by a stationary weight. Forty-four were done during a phase of oedema which varied in degree from simple pitting on pressure over the shins to gross anasarca. The results are summarized in table 1 .

TABLE 1

AVERAGES OBTAINED OF EIGHTY-THREE DUPLICATED BLOOD COUNTS ON VENOUS AND CAPILLARY BLOOD IN OEDEMATOUS AND IN NON-OEDEMATOUS INDIVIDUALS

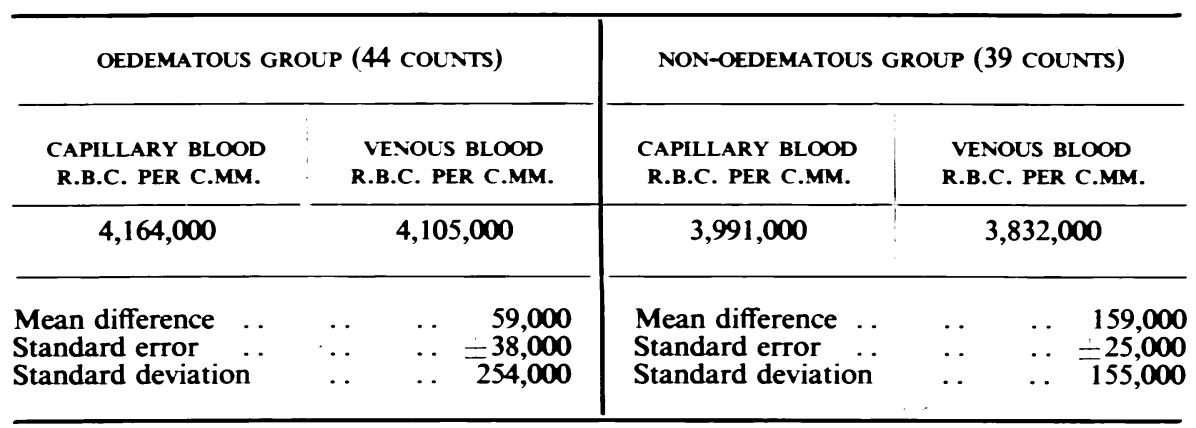

Standard error of the difference between the mean differences: 46,000

In the non-oedematous group the capillary blood is $159,000( \pm 25,000)$ red blood cells per c.mm. more concentrated than the venous blood. If excessive tissue fluid produces dilution of capillary blood during its collection then the increased red cell concentration of the capillary blood in the oedematous group should be less than 159,000 per c.mm. The figures in table 1 reveal that the mean difference between the averages in the oedematous group is indeed less than 159,000 , namely, $59,000( \pm 38,000)$ red blood cells per c.mm. That is to say, the presence of oedema has, on the average, produced a false dilution of 100,000 red blood cells per c.mm. and it remains to calculate whether such a figure is statistically significant. To be significant the diminution in concentration of capillary blood should be more than twice the standard error of the difference between the mean differences which is 46,000 . This proved to be the case in the present instance.

This difference in the counts in the two groups is capable of two explanations. The diminution in the relative concentration of the capillary blood in the oedematous group may be due to dilution of the blood flowing from the punctured lobe of the ear by excessive tissue fluid. On the other hand, the 
extra congestion of the veins necessary to secure a sample of venous blood in an oedematous subject may produce some concentration of the blood in the veins.

It is impossible to state which of these processes is predominant and, almost certainly, both contribute something to the result. If the first suggestion is correct it would be preferable to do all blood counts on venous blood when studying anaemia in nephritis. But the accuracy of individual counts must also be considered since it is with individual counts, during oedema and after it has subsided, that the observations on the degree of anaemia of a patient will be judged subsequently. Examination of the individual counts shows that the venous counts on any one subject have a much wider week-to-week variation than have the capillary counts. This is shown in table 1 where the standard deviation of the differences in the oedematous group $(254,000)$ is considerably larger than that in the non-oedematous group $(155,000)$.

From these results it appears that in the presence of oedema blood counts made either from capillary or venous blood are subject to error. In the former there is some degree of dilution, in the latter of concentration. In neither case, however, is the error great, and in view of the fact that capillary blood is much more easily withdrawn than venous, all counts have been made from blood obtained by skin puncture. It must, however, be borne in mind that in capillary blood oedema may produce a false lowering of the red cell count by about 100,000 red blood cells per c.mm. and a proportionate reduction in haemoglobin and other blood constituents.

\section{The material investigated and the results obtained}

Thirty-six cases of nephritis were studied by the methods detailed above. They fall into the following four classes.

(1) Acute haemorrhagic nephritis-21 cases.

(2) The nephrotic syndrome (Volhard and Fahr) - 5 cases.

(3) Nephrosclerosis-5 cases.

(4) Chronic haemorrhagic nephritis- 5 cases.

Acute haemorrhagic nephritis. (Tables 2 and 3). All the patients in this group showed the typical signs and symptoms of the disease. Their illness was characterized by sudden onset, often after a streptococcal infection, with constitutional symptoms such as headache, vomiting, anorexia and pain in the back; with two exceptions all of them gave a history of oedema at the onset of the disease and sixteen were oedematous on admission. All had albuminuria, haematuria and hyaline, granular and blood casts in the urine; the blood pressure was above normal in all but three cases. In about half of the cases the non-protein nitrogen was above $\mathbf{4 0} \mathrm{mgm}$. per cent. at the first examination. All except one of the cases were well and had a normal urine within three months of the onset of the disease. In the single exception nearly seven months elapsed before the urine was free of albumin.

In table 2 the results of the blood examinations made during the acute stage of the disease are shown. From this it will be seen that there is a moderate 
degree of anaemia and a colour index of 0.9. The mean packed cell volume of 36.7 per cent. is reduced below the normal of 46.6 per cent. in almost exactly the same proportion as the reduction in the red cell count, and gives a normal mean corpuscular volume of 86 cubic microns.

TABLE 2

THE BLOOD IN ACUTE NEPHRITIS EARLY IN THE DISEASE AND DURING CONVALESCENCE

\begin{tabular}{|c|c|c|c|c|c|c|c|c|c|}
\hline \multicolumn{5}{|c|}{ SOON AFTER ADMISSION TO HOSPITAL } & \multicolumn{5}{|c|}{6 TO 8 WEEKS AFTER ADMISSION TO HOSPITAL } \\
\hline NAME & $\begin{array}{l}\text { RED } \\
\text { CELLS } \\
\text { PER } \\
\text { C.MM. }\end{array}$ & $\begin{array}{l}\text { Hb. } \\
\text { PER } \\
\text { CENT. } \\
\text { (HAL- } \\
\text { DANE) }\end{array}$ & $\begin{array}{l}\text { WHITE } \\
\text { CELLS } \\
\text { PER } \\
\text { C.MM. }\end{array}$ & $\begin{array}{c}\text { R.B.C. } \\
\text { VOL. } \\
\text { PER } \\
\text { CENT. }\end{array}$ & NAME & $\begin{array}{c}\text { RED } \\
\text { CELLS } \\
\text { PER } \\
\text { C.MM. }\end{array}$ & \begin{tabular}{|c|} 
Hb. \\
PER \\
CENT. \\
(HAL- \\
DANE)
\end{tabular} & $\begin{array}{l}\text { WHITE } \\
\text { CELLS } \\
\text { PER } \\
\text { C.MM. }\end{array}$ & $\begin{array}{l}\text { R.B.C. } \\
\text { VOL. } \\
\text { PER } \\
\text { CENT. }\end{array}$ \\
\hline $\begin{array}{l}\text { D. F. } \cdots \\
\text { A. J. } \\
\text { E. R. } \cdots \\
\text { W. S. } \cdots \\
\text { M. E. } \cdots \\
\text { E. McI. } \\
\text { I. M. } . \\
\text { R. M. } \\
\text { G. H. } \\
\text { H. G. } \\
\text { M. W. } \\
\text { G. G. } \\
\text { F. C. }\end{array}$ & $\begin{array}{l}4,033,500 \\
4,025,000 \\
4,755,000 \\
4,205,000 \\
4,735,000 \\
4,965,000 \\
4,235,000 \\
3,985,000 \\
4,520,000 \\
3,730,000 \\
3,730,000 \\
3,660,000 \\
4,265,000\end{array}$ & $\begin{array}{l}80 \\
72 \\
74 \\
84 \\
92 \\
90 \\
72 \\
70 \\
92 \\
70 \\
72 \\
72 \\
74\end{array}$ & $\begin{array}{r}11,400 \\
13,200 \\
12,700 \\
22,900 \\
7,200 \\
13,300 \\
15,200 \\
12,500 \\
11,900 \\
18,500 \\
7,300 \\
14,800 \\
14,200\end{array}$ & $\begin{array}{l}40 \cdot 6 \\
35 \cdot 0 \\
-70 \cdot 4 \\
42 \cdot 9 \\
46 \cdot 6 \\
39 \cdot 6 \\
35 \cdot 8 \\
43 \cdot 5 \\
38 \cdot 4 \\
39 \cdot 1 \\
33 \cdot 8 \\
37 \cdot 1\end{array}$ & $\begin{array}{l}\text { E. R. . } \\
\text { W. S. . } \\
\text { M. E. . } \\
\text { E. McI. } \\
\text { G. H. . } \\
\text { G. C. . } \\
\text { F. C. . } \\
\text { E. M. . } \\
\text { F. G. . } \\
\text { A. R. . } \\
\text { D. T. . } \\
\text { W. H. . } \\
\text { M. S. . }\end{array}$ & $\begin{array}{r}4,560,000 \\
4,645,000 \\
4,540,000 \\
4,785,000 \\
3,750,000 \\
4,440,000 \\
5,210,000 \\
4,135,000 \\
4,525,000 \\
3,520,000 \\
4,410,000 \\
3,800,000 \\
4,050,000\end{array}$ & $\begin{array}{l}80 \\
93 \\
86 \\
90 \\
78 \\
90 \\
90 \\
70 \\
78 \\
72 \\
86 \\
72 \\
83\end{array}$ & $\begin{array}{r}11,100 \\
11,000 \\
8,300 \\
11,300 \\
11,700 \\
7,100 \\
8,600 \\
9,000 \\
8,400 \\
8,900 \\
5,800 \\
8,000 \\
4,900\end{array}$ & $\begin{array}{l}- \\
\overline{-} \\
46 \cdot 5 \\
36 \cdot 1 \\
44 \cdot 6 \\
\overline{-} \\
37 \cdot 8 \\
37 \cdot 2 \\
30 \cdot 0 \\
38 \cdot 0 \\
35 \cdot 0 \\
40 \cdot 5\end{array}$ \\
\hline M. S. $\cdots$ & $\begin{array}{l}4,930,000 \\
3,985,000\end{array}$ & $\begin{array}{l}88 \\
78\end{array}$ & 16,300 & $\begin{array}{l}43 \cdot 0 \\
38 \cdot 8\end{array}$ & Averages & $4,340,000$ & 82 & 8,800 & $38 \cdot 4$ \\
\hline $\begin{array}{l}\text { F. G. } \quad \cdots \\
\text { A. R. } \\
\text { D. T. } \\
\text { W. H. } \\
\text { M. S. } \\
\end{array}$ & $\begin{array}{l}4,715,000 \\
3,665,000 \\
4,785,000 \\
3,585,000 \\
4,650,000\end{array}$ & $\begin{array}{l}80 \\
70 \\
88 \\
72 \\
82\end{array}$ & $\begin{array}{r}11,600 \\
11,000 \\
8,200 \\
15,000 \\
9,800\end{array}$ & $\begin{array}{l}38.5 \\
34.0 \\
39.0 \\
30.0 \\
35.0\end{array}$ & \multicolumn{5}{|c|}{$\begin{array}{l}\text { Averages of above group on admission } \\
\text { (extracted from first table) }\end{array}$} \\
\hline Averages & $4,289,000$ & 77 & 13,700 & $36 \cdot 7$ & \multicolumn{2}{|c|}{$4,390,000$} & $79 \cdot 8$ & 13,800 & \\
\hline
\end{tabular}

Average colour index 0.9 .

Average individual red cells volume, 86 cubic microns.

Eight of the patients in the first table are omitted from the second table. They had been dismissed home before six weeks had elapsed.

Thus, on the first examination the patients in this group presented a slight normocytic anaemia with a colour index of $0 \cdot 9$, a blood picture which, according to Parsons and Ekola-Strolberg (1933), may be considered to be orthochromic: there was also a moderate leucocytosis. As these counts only showed the state of the blood in the early stages of the disease the possibility had to be considered that anaemia had not then occurred, and that estimations made some time later might disclose its subsequent development. Of the twenty-one patients in this group eight were dismissed from hospital within six weeks of the first counts being made. In the remaining thirteen patients the results of the blood examination, made six to eight weeks later, are given in table 2. 
This shows that there has been no increase in the anaemia, but that the leucocytosis has disappeared.

It would appear from these results that early in acute nephritis there is a slight orthochromic, normocytic anaemia with slight leucocytosis and that when convalescence is established the anaemia persists though there is no longer leucocytosis. During the course of the illness, however, definite changes in the blood picture were observed in all cases in which there was oedema. In table 3 the red cell counts are shown at three stages of the disease: (1) when

TABLE 3

RED CELL COUNTS IN DIFFERENT PHASES OF ACUTE NEPHRITIS

\begin{tabular}{|c|c|c|c|c|c|c|}
\hline \multirow[b]{2}{*}{ No. } & \multirow{2}{*}{\multicolumn{2}{|c|}{ NAME }} & & \multicolumn{3}{|c|}{ RED CELLS PER C.MM. } \\
\hline & & & & $\begin{array}{c}\text { OEDEMA } \\
+ \text { OR }++\end{array}$ & $\begin{array}{c}\text { FIRST RECORD } \\
\text { WHEN NO OEDEMA } \\
\text { DUURESIS }++\frac{+}{+}\end{array}$ & $\begin{array}{l}4 \text { TO } 5 \text { WEEKS } \\
\text { LATER NO OEDEMA } \\
\text { NO DUURESS }\end{array}$ \\
\hline $\begin{array}{r}1 \\
2 \\
3 \\
4 \\
5 \\
6 \\
7 \\
8 \\
9 \\
10 \\
11 \\
12\end{array}$ & $\begin{array}{l}\text { D. F. } \\
\text { A. J. } \\
\text { E. R. } \\
\text { W. S. } \\
\text { R. M. } \\
\text { M. W. } \\
\text { G. C. } \\
\text { F. C. } \\
\text { M. M. } \\
\text { A. R. } \\
\text { D. T. } \\
\text { W. H. }\end{array}$ & $\begin{array}{l}\ldots \\
\ldots \\
\ldots \\
\cdots \\
\cdots \\
\cdots \\
\cdots \\
\cdots \\
\cdots \\
\cdots\end{array}$ & $\begin{array}{l}\cdots \\
\cdots \\
\cdots \\
\cdots \\
\cdots \\
\cdots \\
\cdots \\
\cdots \\
\cdots \\
\cdots\end{array}$ & $\begin{array}{l}4,335,000 \\
4,025,000 \\
4,755,000 \\
4,205,000 \\
3,985,000 \\
3,730,000 \\
3,660,000 \\
4,265,000 \\
3,985,000 \\
3,665,000 \\
4,785,000 \\
3,585,000\end{array}$ & $\begin{array}{l}5,160,000 \\
5,130,000 \\
5,115,000 \\
4,635,000 \\
4,375,000 \\
4,065,000 \\
4,315,000 \\
5,455,000 \\
4,640,000 \\
4,210,000 \\
5,020,000 \\
4,340,000\end{array}$ & $\begin{array}{c}\text { Irreg. Dismissal } \\
4,010,000 \\
4,440,000 \\
4,325,000 \\
- \\
\overline{4}, \overline{000,000} \\
4,770,000 \\
4,045,000 \\
3,825,000 \\
4,410,000 \\
3,655,000\end{array}$ \\
\hline \multicolumn{2}{|c|}{ Averages * } & $\cdots$ & 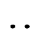 & $4,103,000$ & $4,762,000$ & $4,164,000$ \\
\hline
\end{tabular}

(* Excluding no. 1, 5 and 6.)

oedema was manifest; (2) immediately after all clinical oedema had disappeared - the time when diuresis was most marked; (3) four weeks later when the weight was steady and the vascular water exchange was balanced. Only twelve of the twenty-one cases in this group are included, as the other children, when first examined, either had no oedema or were already in the stage when diuresis had begun. It will be seen that there was a pronounced rise in the red cell count during the period of diuresis and that the red cell count returned to its original level when oedema had disappeared and diuresis had ceased. This is illustrated in chart I, which shows the changes in the blood of W. H., a typical case of acute nephritis with oedema; similar changes occurred in all the other cases.

The nephrotic syndrome (tables 4 and 5). Although it is generally recognized that anaemia is not a feature of nephrosis there is difficulty in estimating the true state of the blood as there are variations in the blood count according to the stage of the disease at which the examination is made. In table 4 the red cell count, the haemoglobin percentage, the white cell count and the red cell volume in five children showing the nephrotic syndrome are given. These 
CBMRI I.

Chart to Show the Relationship Between the Red Cell

Count, Dofree of Dedena and Urinary Excretion

in Acute Nephritis.

W.H. 7 years. Acute Nephritis.

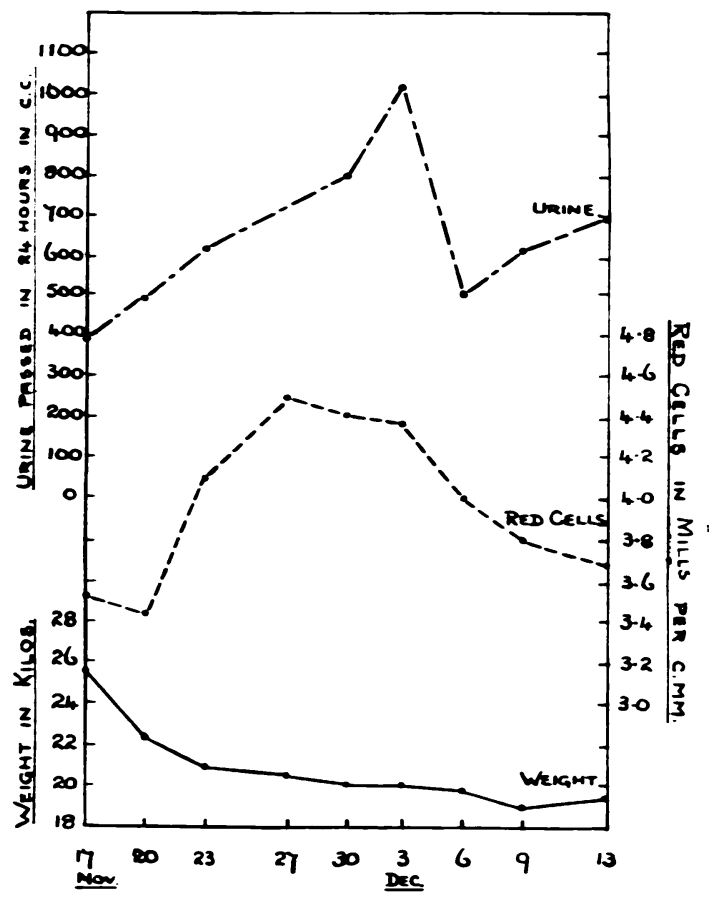

TABLE 4

THE BLOOD IN THE NEPHROTIC SYNDROME

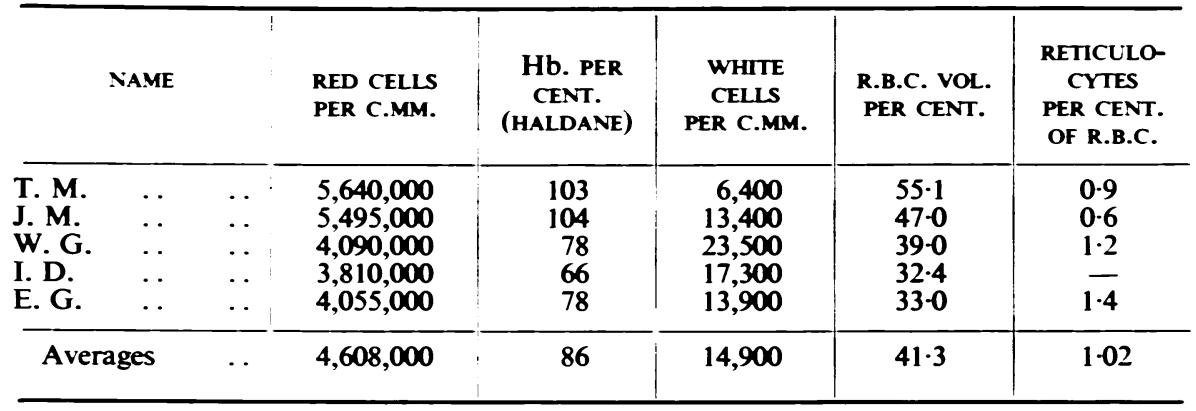

Average colour index 0.93.

Average mean corpuscular volume $90 \mathrm{c}$. microns.

figures represent the state of the blood on admission to hospital. They do not, however, necessarily show whether true anaemia is present or not as the 
possibility that the fluid constituents of the blood may have passed out of the circulation into the tissues and led to haemoconcentration must be taken into consideration, nor can the possible influence of infections be overlooked. A brief summary of the course of the disease in each patient during his stay in hospital affords evidence of the part played by disturbance of fluid distribution and of the influence of infections as a cause of anaemia in this disease.

TABLE 5

NEPHROTIC SYNDROME

BLOOD AND URINARY FINDINGS DURING PERIODS OF INCREASING AND DIMINISHING OEDEMA

\begin{tabular}{|c|c|c|c|c|c|c|c|}
\hline NAME & OEDEMA & $\begin{array}{c}\text { Hb } \\
\text { PER } \\
\text { CENT. }\end{array}$ & $\begin{array}{l}\text { R.B.C. } \\
\text { PER C.MM. }\end{array}$ & $\begin{array}{c}\text { CELL } \\
\text { VOL. } \\
\text { PER } \\
\text { CENT. }\end{array}$ & $\begin{array}{l}\text { URINE } \\
\text { C.C. } \\
24 \text { HR. }\end{array}$ & $\begin{array}{l}\text { N.P.N. } \\
\text { MGM. } \\
\text { PER } \\
\text { CENT. }\end{array}$ & $\begin{array}{c}\text { BLOOD } \\
\text { Cl } \\
\text { MGM. } \\
\text { PER } \\
\text { CENT. }\end{array}$ \\
\hline J. M. . & $\begin{array}{l}\text { Increasing } \\
\text { Diminishing }\end{array}$ & $\begin{array}{r}104 \\
96\end{array}$ & $\begin{array}{l}5,495,000 \\
4,910,000\end{array}$ & $\begin{array}{l}47.0 \\
40.0\end{array}$ & $\begin{array}{l}480 \\
570\end{array}$ & $\begin{array}{l}32 \cdot 4 \\
22 \cdot 7\end{array}$ & $\begin{array}{l}443 \\
472\end{array}$ \\
\hline W. G. & $\begin{array}{l}\text { Increasing } \\
\text { Diminishing }\end{array}$ & $\begin{array}{l}95 \\
82\end{array}$ & $\begin{array}{l}4,815,000 \\
4,110,000\end{array}$ & $\begin{array}{l}46 \cdot 3 \\
40 \cdot 0\end{array}$ & $\begin{array}{l}660 \\
640\end{array}$ & $\begin{array}{l}24.9 \\
19 \cdot 0\end{array}$ & $\begin{array}{l}410 \\
484\end{array}$ \\
\hline T. M... & \begin{tabular}{l|l}
.. Increasing \\
& $*$ Diminishing
\end{tabular} & $\begin{array}{r}103 \\
68\end{array}$ & $\begin{array}{l}5,640,000 \\
3,670,000\end{array}$ & $\begin{array}{l}55 \cdot 1 \\
36 \cdot 2\end{array}$ & $\begin{array}{r}230 \\
1350\end{array}$ & $\begin{array}{l}35.7 \\
25.9\end{array}$ & $\begin{array}{l}432 \\
443\end{array}$ \\
\hline
\end{tabular}

* The low results for T. M. when oedema was diminishing were due to the super-added effect of infection.

T. M. Admitted 20.7.38. Age 6 years 11 months. During his first three years the boy had frequent minor chest complaints, but thereafter remained healthy until two days before admission, when his face became puffy and on the following day he had swelling of his face, abdomen, scrotum, back and legs.

On admission he had anasarca and ascites with oliguria, albuminuria (28 parts Esbach), casts and scanty red cells in the urine. Blood pressure $122 / 92 \mathrm{~mm}$. $\mathrm{Hg}$. The Mantoux tuberculin test was negative. Temperature, pulse and respirations were normal. Oedema at this time was increasing. The blood examination gave the following results:

\begin{tabular}{|c|c|c|}
\hline RED BLOOD CELLS & . & $5,640,000$ per c.mm \\
\hline HAEMOGLOBIN & . & 103 per cent. \\
\hline WHITE BLOOD CELLS & . & 6400 per c.mm. \\
\hline RETICULOCYTES . & .. & 0.9 per cent. \\
\hline RED BLOOD CELL VOLUME & . & $55 \cdot 1$ per cent. \\
\hline SERUM PROTEIN $\quad \ldots$ & & $5 \cdot 13 \mathrm{gm}$. per cent. \\
\hline NON-PROTEIN NITROGEN & .. & $35.7 \mathrm{mgm}$. per cent. \\
\hline
\end{tabular}

After one week he developed an erysipelatous rash followed by an empyema and in the course of four weeks his blood picture changed greatly.

\begin{tabular}{|c|c|c|}
\hline RED BLOOD CELLS & .. & $3,160,000$ per c.mm \\
\hline HAEMOGLOBIN & . & 52 per cent. \\
\hline WHITE BLOOD CELLS & . & 23,400 per c.mm. \\
\hline RETICULOCYTES . & & $2 \cdot 6$ per cent. \\
\hline RED BLOOD CELL VOLLME & & 35.9 per cent. \\
\hline SERUM PROTEIN $\quad \ldots$ & & 5.25 gm. per cent. \\
\hline NON-PROTEIN NITROGEN & . & $35.2 \mathrm{mgm}$. per cent. \\
\hline
\end{tabular}


The blood pressure was $134 / 100 \mathrm{~mm}$. Hg. The empyema was treated by rib resection and he was dismissed from hospital on 19.11.38 apparently well. There was no oedema, the blood pressure was $108 / 80 \mathrm{~mm}$. $\mathrm{Hg}$, the urine was free from albumin and blood and the following figures show that his blood had become normal.

$\begin{array}{llllll}\text { RED BLOOD CELLS } & \ldots & \ldots & \ldots & \ldots & 5,225,000 \text { per c.mm. } \\ \text { HAEMOGLOBIN } & . & \ldots & \ldots & \ldots & 96 \text { per cent. } \\ \text { WHITE BLOOD CELLS } & \ldots & \ldots & \ldots & 8,600 \text { per c.mm. } \\ \text { RETICULOCYTES } & . & . & \ldots & \ldots & 0.9 \text { per cent. } \\ \text { RED BLOOD CELL VOLUME } & \ldots & \ldots & \ldots & 47.0 \text { per cent. } \\ \text { SERUM PROTEIN } & \ldots & \ldots & \ldots & 7.32 \text { gm. per cent. } \\ \text { NON-PROTEIN NITROGEN } & \ldots & \ldots & \ldots & 41.7 \text { mgm. per cent. }\end{array}$

He remained well, at home, for two weeks and was then re-admitted to hospital with clinical, biochemical and haematological findings as on his first admission. Anasarca and ascites became extreme and his abdomen was tapped several times. After approximately six months of varying degrees of oedema he again developed erysipelas and pneumonia complicated by empyema. Associated with this there were severe anaemia and well sustained leucocytosis reaching 46,400 white blood cells per c.mm. (chart II). He died as a result of the pulmonary infection. In this last infection his blood count fell as low as $1,825,000$ red blood cells per c.mm. and haemoglobin to 36 per cent.. while the reticulocyte count varied between 5 per cent. and 10 per cent.

CHART II

Chart to show the Rolationship between the Incidence of Anaenta and Infection in Nephrotic Syndrome.

T.M. 7 years. Nephrotic Syndrome.

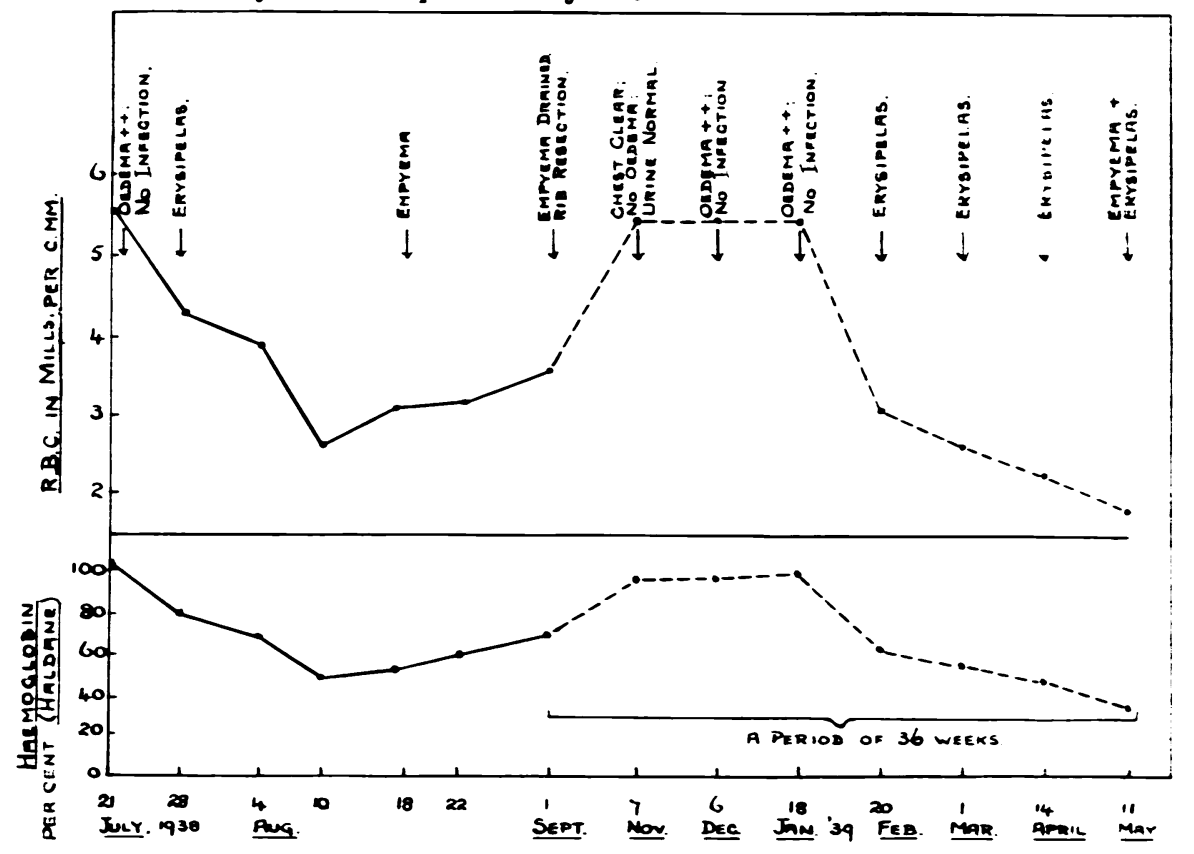


The post-mortem examination revealed a left-sided empyema with a collection of pus under the diaphragm and bilateral pneumonic consolidation. The kidneys presented the typical characteristics found in lipoid nephrosis.

J. McD. Admitted 7.7.36. Aged 3 years 10 months. The boy had a normal, healthy childhood until two weeks before admission when his face became puffy and oedema rapidly spread over his whole body.

On admission there was anasarca and ascites with oliguria. The urine contained much albumin and many casts, but only scanty red cells. The Mantoux test was negative, the blood pressure $110 / 59 \mathrm{~mm}$. $\mathrm{Hg}$, the blood urea $28 \mathrm{mgm}$. per cent. and the serum protein $4.9 \mathrm{gm}$. per cent.

Since then he spent most of his life in hospital with waxing and waning oedema, but no impairment of renal function as shown by the urea clearance tests. During one week when he had a sudden increase in oedema his blood count was red blood cells 6,185,000 per c.mm., haemoglobin 126 per cent., and a week later when oedema was diminishing the count fell to red blood cells 4,790,000 per c.mm., haemoglobin 98 per cent. The boy repeatedly showed fluctuations in his red cell count associated with oedema similar to the example quoted, though less extreme. Although he was seldom oedema free, his general health remained fairly good until May and June, 1939, when he had several brief attacks of cellulitis of his thighs and abdominal wall with associated constitutional upset. On each of these occasions there was a sudden fall in the red cell count. Ultimately on June 23,1939 , he developed cellulitis of his legs, thighs and abdominal wall which led to generalized pneumococcal peritonitis and death exactly three years after the onset of his illness. In the

CHART III

Graph to Show the Relationship Between Red Cell Count, Degree

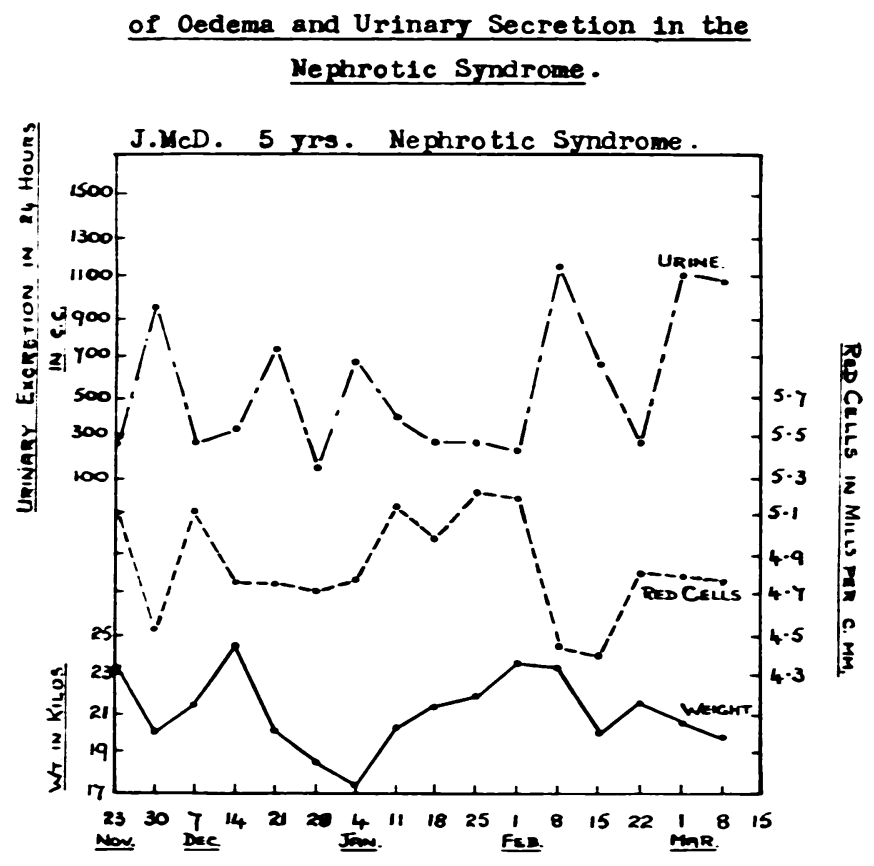


course of this fatal infection he developed severe anaemia. Blood examination gave the following results:

$\begin{array}{llllll}\text { RED BLOOD CELLS } & \ldots & \ldots & \ldots & \ldots & 2,785,000 \text { per c.mm. } \\ \text { HAEMOGLOBIN } & . & \ldots & \ldots & \ldots & 48 \text { per cent. } \\ \text { COLOUR INDEX } & . & \ldots & \ldots & \ldots & 0.9 . \\ \text { WHITE BLOOD CELLS } & \ldots & \ldots & \ldots & 27,300 \text { per c.mm. } \\ \text { RETICULOCYTES } & . & \ldots & \ldots & \ldots & \mathbf{4 . 0} \text { per cent. }\end{array}$

The non-protein nitrogen was $34.2 \mathrm{mgm}$. per cent. and the serum protein $5.73 \mathrm{gm}$. per cent. His urinary output became scanty, contained albumin and occasionally a few red blood cells, and the chloride content was low. The blood pressure was $98 / 78 \mathrm{~mm}$. $\mathrm{Hg}$.

On post-mortem examination he was found to have a generalized pneumococcal peritonitis; no lung lesion; the heart and blood vessels were normal and both kidneys presented the characteristic picture of nephrosis.

W. G. Admitted 27.12.37. Aged 6 years. The boy had bone tuberculosis at four years. In December, 1936, he spent five months in another hospital with nephritis and oedema. After being at home for one month he was admitted to still another hospital where he remained for five months with nephritis and oedema. He was at home again for one month and then was admitted to this hospital with widespread oedema and ascites, gross albuminuria and many casts, but no red cells in his urine. The Mantoux test was positive.

On admission the blood findings were as follows:

$\begin{array}{llllll}\text { RED BLOOD CELLS } & . & \ldots & \ldots & \ldots & 4,090,000 \text { c.mm. } \\ \text { HAEMOGLOBIN } & . & \ldots & \ldots & \ldots & 78 \text { per cent. } \\ \text { WHITE BLOOD CELLS } & \ldots & \ldots & \ldots & 23,500 \text { per c.mm. } \\ \text { RETICULOCYTES } & . & . & \ldots & \ldots & 1.2 \text { per cent. } \\ \text { RED BLOOD CELL VOLUME } & \ldots & \ldots & \ldots & 39.0 \text { per cent. } \\ \text { SERUM PROTEIN } & . & . & \ldots & \ldots & 4.57 \text { gm. per cent. }\end{array}$

The non-protein nitrogen was $27.8 \mathrm{mgm}$. per cent. and the blood pressure $106 / 70 \mathrm{~mm}$. Hg. Oedema gradually disappeared and six months later, when he was transferred to a sanatorium with pulmonary and abdominal tuberculosis, his blood examination gave the following results.

$\begin{array}{llllll}\text { RED BLOOD CELLS } & \ldots & \ldots & \ldots & \ldots & 5,190,000 \text { per c.mm. } \\ \text { HAEMOGLOBIN } & . & \ldots & \ldots & \ldots & \mathbf{9 4} \text { per cent. } \\ \text { WHITE BLOOD CELLS } & \ldots & \ldots & \ldots & \mathbf{1 5 , 3 0 0} \text { per c.mm. } \\ \text { RED BLOOD CELL VOLUME } & \ldots & \ldots & \ldots & \mathbf{4 8 . 3} \text { per cent. } \\ \text { SERUM PROTEIN } & . & . & \ldots & \ldots & 5.96 \text { gm. per cent. }\end{array}$

Non-protein nitrogen was $38.6 \mathrm{mgm}$. per cent. and the blood pressure $94 / 66 \mathrm{~mm}$. Hg. Throughout his stay in hospital his urine contained much albumin, but no red blood cells.

I. D. Admitted 13.7.37. Aged 4 years. The girl had a normal childhood. Three days before admission she became listless with anorexia and vomiting and her face was puffy. On the day of admission her legs and face became swollen and she had severe abdominal pain with nausea and vomiting.

On admission she had anasarca and ascites, fluid in both pleura and her urine contained much albumin, but only occasional red cells and casts. Both fundi were normal; the Wassermann reaction was negative and the blood pressure was $85 / 60 \mathrm{~mm}$. $\mathrm{Hg}$.

Oedema remained extreme until one month after admission when she 
developed peritonitis from which she recovered after ten days. She was very fevered during this time and the serum protein rose to $6.47 \mathrm{gm}$. per cent. with some slight and temporary diminution in oedema. One month later an abscess pointed in the left iliac fossa, was aspirated and cleared up rapidly. Two weeks later the oedema increased and she was given 1 c.c. salyrgan intravenously; this was followed by rapid loss of all oedema. She remained without oedema or albuminuria for about three months. Then the oedema and albuminuria returned and failed to respond to further injections of salyrgan. Thereafter massive oedema was constantly present. During the latter half of November, 1937, she had a respiratory infection and in March, 1938, she developed generalized peritonitis and died. In her case the routine investigations described in this paper were only begun in February, 1938, five weeks before her death. The low blood counts recorded (table 4 ) for this girl are certainly attributable to the infections from which she suffered.

E. G. Admitted 2.11.37. Aged 3 years. The boy had a normal childhood until four days before admission when his face became puffy and the swelling rapidly spread over his body.

On admission he had generalized oedema and the urine showed a large amount of albumin and numerous casts, but no red cells. The Mantoux test was negative. The condition of his blood was as follows:

$\begin{array}{llllll}\text { RED BLOOD CELLS } & \ldots & \ldots & \ldots & \ldots & 4,055,000 \text { per c.mm. } \\ \text { HAEMOGLOBIN } & . & \ldots & \ldots & \ldots & 70 \text { per cent. } \\ \text { WHITE BLOOD CELLS } & \ldots & \ldots & \ldots & 13,900 \text { per c.mm. } \\ \text { RETICULOCYTES .. } & \ldots & \ldots & \ldots & 1.4 \text { per cent. } \\ \text { RED BLOOD CELL VOLLME } & \ldots & \ldots & \ldots & 33.0 \text { per cent. } \\ \text { SERUM PROTEIN } & . & . & \ldots & \ldots & 5.61 \text { gm. per cent. }\end{array}$

The non-protein nitrogen was $23.9 \mathrm{mgm}$. per cent. and the systolic blood pressure $82 \mathrm{~mm}$. $\mathrm{Hg}$.

Ten days later he developed whooping cough and was transferred to a fever hospital. At that time his counts were:

$\begin{array}{llllll}\text { RED BLOOD CELLS } & \ldots & \ldots & \ldots & \ldots & 4,775,000 \text { per c.mm. } \\ \text { HAEMOGLOBIN } & . & \ldots & \ldots & \ldots & 86 \text { per cent. } \\ \text { WHITE BLOOD CELLS } & \ldots & \ldots & \ldots & 22,100 \text { per c.mm. } \\ \text { RETICULOCYTES .. } & \ldots & \ldots & \ldots & 1 \cdot 1 \text { per cent. } \\ \text { RED BLOOD CELL VOLLME } & \ldots & \ldots & \ldots & 42.0 \text { per cent. }\end{array}$

The non-protein nitrogen was $27 \mathrm{mgm}$. per cent. and the blood pressure $9060 \mathrm{~mm}$. $\mathrm{Hg}$ and oedema was diminishing.

It is worthy of note that in contrast to the effects of pyogenic infection observed in the previous case whooping cough did not cause increase in the anaemia in this child.

In order to get a true estimate of the state of the blood in a patient with nephrosis the count must be made when the child is losing oedema or, if possible, when he is oedema free. Only three of these patients ( $\mathrm{J}$. McD.. W. G., T. M.) were observed over periods long enough to justify tabulation of the results. These are presented in table 5 in which the influence of oedema on various blood constituents is recorded. In this table it can be seen that there is a concentration of the blood during increasing oedema and a subsequent dilution during the phase of diminishing oedema. The increase in blood 
chlorides during diminishing oedema is probably due to the transference of tissue fluid with a high chloride content to the blood stream during this phase.

Reference has already been made to the finding of McClure et al. (1933) that during the phase of increasing oedema in nephrosis the red cell count, haemoglobin, and the packed cell volume all increase and when the oedema becomes stationary or is subsiding and diuresis is profuse they fall. Each of the three cases was examined in detail over a sufficiently long period to show these changes. They are well illustrated in table 5 and by the case of J. McD. (chart III). This child was a typical example of the nephrotic syndrome and blood examinations were made on him at weekly intervals over a period of almost eight months as well as at other times. During that period of continuous examination he repeatedly showed the characteristic fluctuations in the blood constituents associated with the waxing and waning of oedema as described above.

One of these children (T. M.) had an acute infection on two occasions and on each a rapidly developing and severe anaemia was observed. On the first occasion the anaemia cleared up entirely after an empyema had been drained and had healed, but on the second occasion the boy died as a result of an empyema and erysipelas of his thighs (chart II). Another child in this group (J. McD.) also developed a severe anaemia associated with an acute infection from which he ultimately died.

The results in tables 4 and 5 and chart III afford further evidence in favour of the general opinion that anaemia is slight or absent in patients with nephrosis so long as they remain free from acute pyogenic infections. The high percentage of reticulocytes found during these acute anaemias indicates that the bone marrow is not rendered aplastic.

Nephrosclerosis and renal dwarfism (chronic interstitial nephritis) (tables 6 and 7). Of the five cases described here one was a renal dwarf and four were cases of chronic interstitial nephritis (nephrosclerosis).

TABLE 6

THE BLOOD IN CHRONIC INTERSTITIAL NEPHRITIS (NEPHROSCLEROSIS) SOON AFTER ADMISSION

\begin{tabular}{|c|c|c|c|c|c|}
\hline NAME & & $\begin{array}{l}\text { RED CELLS } \\
\text { PER C.MM. }\end{array}$ & $\begin{array}{l}\text { Hb. PER CENT. } \\
\text { (HALDANE) }\end{array}$ & $\begin{array}{l}\text { WHITE CELLS } \\
\text { PER C.MM. }\end{array}$ & $\begin{array}{l}\text { R.B.C. VOL. } \\
\text { PER CENT. }\end{array}$ \\
\hline $\begin{array}{l}\text { J. D. } \\
\text { M. McN. } \\
\text { J. C. } \\
\text { R. M. } \\
\text { E. D. }\end{array}$ & $\begin{array}{l}\cdots \\
\cdots \\
\cdots \\
\cdots\end{array}$ & $\begin{array}{l}4,260,000 \\
5,415,000 \\
4,375,000 \\
2,460,000 \\
5,330,000\end{array}$ & $\begin{array}{r}74 \\
108 \\
86 \\
50 \\
99\end{array}$ & $\begin{array}{r}10,800 \\
7,800 \\
11,700 \\
11,200 \\
-\end{array}$ & $\begin{array}{l}40 \cdot 2 \\
44 \cdot 7 \\
43 \cdot 8 \\
24 \cdot 3 \\
41 \cdot 0\end{array}$ \\
\hline Average & $\cdots$ & $4,368,000$ & 83 & 10,400 & 38.8 \\
\hline
\end{tabular}

Colour index 1.0.

Average volume of individual red cells $89 \mathrm{c}$. microns.

The renal dwarf (J. D.) was a boy aged 9 years who was first admitted to hospital in 1936 with double hydronephrosis and chronic pyuria. There was 
thirst, polyuria and fatigue and failure to grow. He was re-admitted with the same symptoms in November, 1938. His systolic blood pressure was $72 \mathrm{~mm}$. $\mathrm{Hg}$ and his urine contained albumin, numerous pus cells and streptococci, but no red blood cells. Skiagrams of his wrists showed signs of rickets. Both fundi were normal. The non-protein nitrogen was $83.3 \mathrm{mgm}$. per cent. and the serum protein $7.35 \mathrm{gm}$. per cent. Three of the other four cases (M. McN., J. C., E. D.) were all advanced examples of nephrosclerosis. In each the onset was insidious with headache and vomiting as prominent features and none of them gave any history of an acute attack of nephritis. They never had any oedema and not more than one or two red cells were ever found in their urine during the time they were in hospital. The systolic blood pressure was over $200 \mathrm{~mm}$. $\mathbf{H g}$ in each case and there was mild albuminuria. All had azotaemia and well-marked neuro-retinitis and retinal haemorrhages.

The remaining child (R. M.) was similar to the three cases described above except that she had gross haematuria for four weeks before admission. This child had severe anaemia on admission (see table 6) and died eight days later. She had a reticulocytosis of 5 per cent., the non-protein nitrogen was $142 \cdot 8 \mathrm{mgm}$. per cent. and the serum protein $7.23 \mathrm{gm}$. per cent., the red cell volume was 24.3 per cent. and the indirect van den Bergh reaction amounted to only 1 unit. The blood pressure was $190 / 130 \mathrm{~mm}$. $\mathrm{Hg}$. The child's urine was bright red with fresh blood. The post-mortem examination on this girl disclosed a long standing chronic nephritis with a small atrophic right kidney and a large left kidney. There were developmental abnormalities in the vascular system of the right kidney with stenosis of the right renal artery.

Reference to table 6 shows that in this series of patients with nephrosclerosis no conspicuous anaemia has been found in the absence of haemorrhage and accordingly we cannot agree with the suggestion of Parsons and Ekola-Strolberg (1933) that anaemia and azotaemia are closely related. That there is no interference with haemopoiesis in this type of nephritis is well shown by two of these patients, E. D. and R. M. In the first the red cell count was over five millions per c.mm. in October (table 7). About three weeks later several carious teeth were extracted and during that night she had a severe haemorrhage from the tooth sockets, and in the course of the next few days her red cell count fell below 3 millions per c.mm. She developed an immediate reticulocyte

TABLE 7

THE BLOOD FOLLOWING HAEMORRHAGE IN CHRONIC INTERSTITIAL NEPHRITIS

\begin{tabular}{|c|c|c|c|c|c|c|c|}
\hline NAME & & DATE & $\begin{array}{l}\text { RED CELLS } \\
\text { PER C.MM. }\end{array}$ & $\begin{array}{c}\text { Hb. } \\
\text { PER CENT. } \\
\text { (HALDANE) }\end{array}$ & $\begin{array}{l}\text { R.B.C. } \\
\text { VOL. } \\
\text { PER CENT. }\end{array}$ & $\begin{array}{l}\text { WHITE } \\
\text { CELLS } \\
\text { PER C.MM. }\end{array}$ & $\begin{array}{l}\text { RETICLLO- } \\
\text { CYTES } \\
\text { PER CENT. } \\
\text { OF R.B.C. }\end{array}$ \\
\hline $\begin{array}{l}\text { E. D. . } \\
\text { R. M... }\end{array}$ & . & $\begin{array}{c}16.10 .37 \\
11.11 .37 \\
25.11 .37 \\
24.2 .38\end{array}$ & $\begin{array}{l}5,330,000 \\
2,970,000 \\
4,025,000 \\
2,460,000\end{array}$ & $\begin{array}{l}99 \\
58 \\
80 \\
50\end{array}$ & $\begin{array}{l}41 \\
24 \\
33 \\
24 \cdot 3\end{array}$ & $\begin{array}{r}\overline{11,800} \\
10,800 \\
11,200\end{array}$ & $\begin{array}{l}-\overline{4 \cdot 6} \\
3 \cdot 2 \\
5 \cdot 0\end{array}$ \\
\hline
\end{tabular}


response of 4 to 5 per cent. and within two weeks her count had risen from below 3 millions to over 4 millions per c.mm. and her haemoglobin from 58 to 80 per cent. She then left hospital and further examination was impossible.

In the second (R. M.), who had gross haemorrhage from the renal pelvis producing a severe anaemia, the blood contained 5 per cent. of reticulocytes when the patient was almost moribund, a finding which excludes the possibility of marrow aplasia (table 7).

Chronic haemorrhagic nephritis. (Tables 8 and 9). The five patients in this group were all suffering from a chronic form of nephritis. In four cases there was a clear account of an initial attack of acute nephritis with haematuria, oedema and constitutional upset. In the other case (P. C.) the illness dated from an attack of pneumonia eight months before admission. He was known to have albuminuria immediately after the pneumonia.

All of these children had albuminuria, haematuria, and numerous casts in their urine. The systolic blood pressure was not greatly increased, ranging from 120 to $130 \mathrm{~mm}$. $\mathrm{Hg}$, there was a moderate degree of azotaemia, and oedema that varied in amount from time to time.

The cases in this group are considered to constitute an entirely different disease from nephrosclerosis (van Slyke et al. 1930). They differ from it in that the disease began as an apparently simple acute nephritis which passed into a subacute and chronic stage with haematuria, oedema and only moderate hyperpiesia. In nephrosclerosis, on the other hand, the onset is insidious, there is never any haematuria and never oedema and there is, except in renal dwarfism, a very high blood pressure with associated retinal changes. Brief notes on the five cases indicate the main clinical findings and the chronic nature of the disease.

M. R. Female, aged 5 years. Admitted 8.9.38, discharged 3.4.39. Recurrent tonsillitis during the past year; frequency of micturition and enuresis for past month. Two weeks before admission tonsillitis and swelling of face with haematuria during past four days and vomiting for one day.

ON ADMission. The child had puffy eyes and oedema of the shins. The urine was loaded with albumin and moderate haematuria was found. Three weeks later she suffered from catarrhal jaundice which lasted for ten days. Thereafter there was no oedema, but haematuria continued as before. Some haemorrhage from tooth sockets occurred during the first week in October. Special investigations began on 18.10 .38 when the following data were recorded:

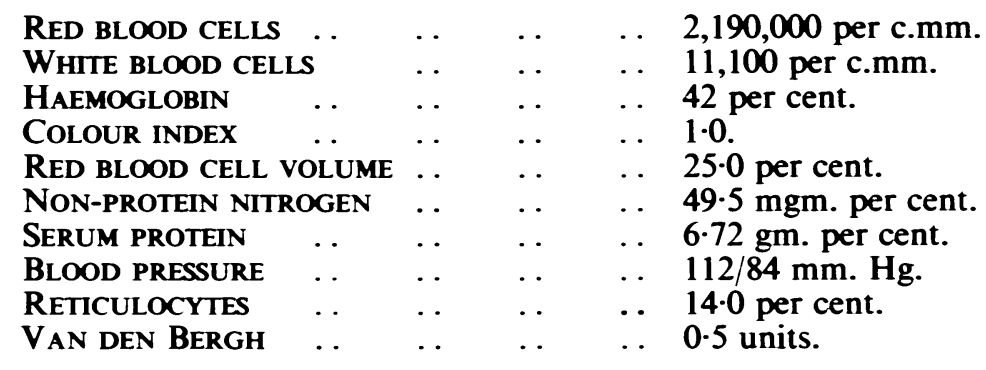




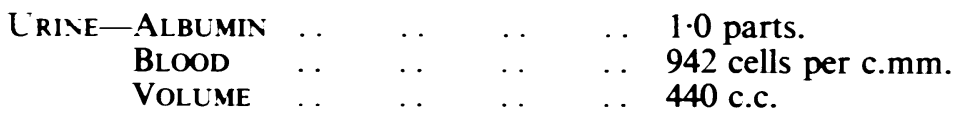

Thereafter her general health remained unchanged with albuminuria and haematuria persisting until she was discharged on 3.4.39. Haematinic treatment was rather ineffectual as may be seen from the findings on discharge:

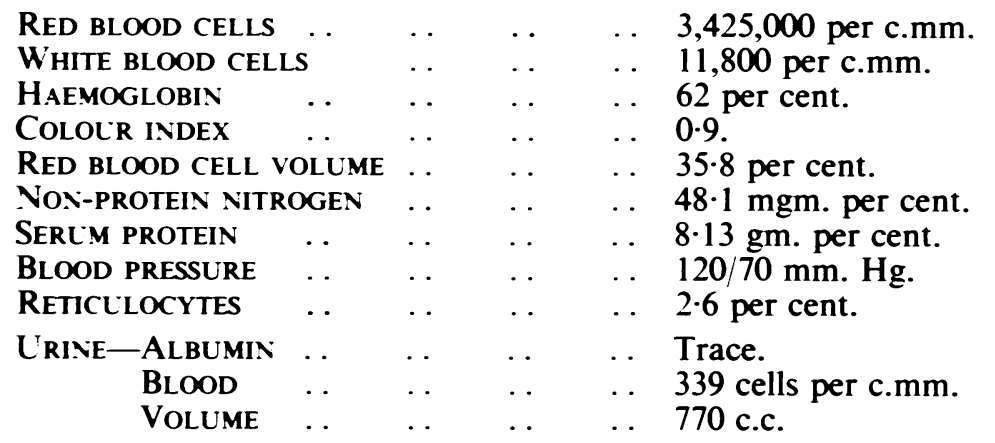

P. C. Male, aged 7 years. Admitted 7.11.38, discharged 5.4.39.

History. Whooping cough at $2 \frac{1}{2}$ years. Scarlet fever at 3 years. Chicken pox at $3 \frac{1}{2}$ years. Measles at 4 years. Diphtheria at $4 \frac{1}{2}$ years. In March, 1938. he had pneumonia and was in hospital for two months, and since then had albuminuria, face puffy in mornings and occasional swelling of feet.

Ox ADMISSION. Slight oedema was found. His tonsils were moderately enlarged and unhealthy. These were removed in January, 1939. The blood and urine findings were as follows:

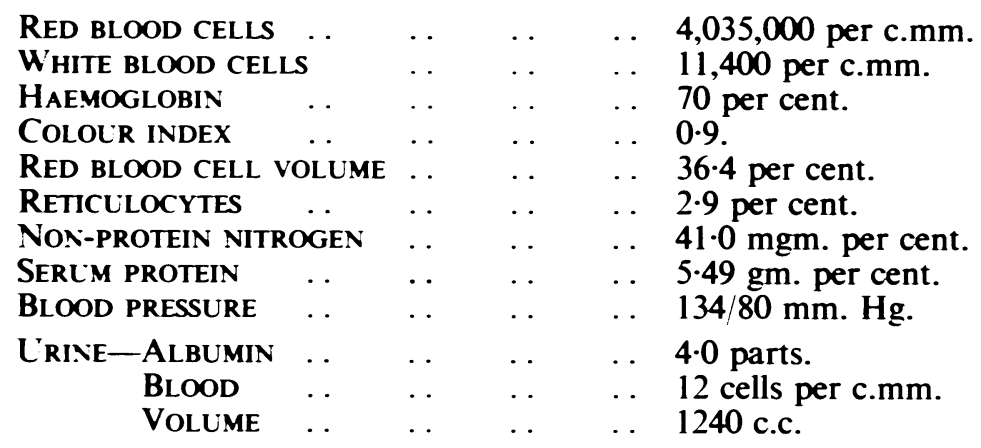

Oedema gradually disappeared, but otherwise his condition remained more or less unchanged. The reticulocyte count varied between 0.6 per cent. and $3 \cdot 1$ per cent., but in spite of treatment with iron, liver and ascorbic acid anaemia persisted. On 4.4.39 the following blood and urine findings were recorded:

\begin{tabular}{|c|c|c|}
\hline RED BLOOD CELLS & & $4,050,000$ per c.mm. \\
\hline WHITE BLOOD CELLS & . & 11,000 per c.mm. \\
\hline HAEMOGLOBIN . & . & 76 per cent. \\
\hline COLOLR INDEX . & . & 0.9 . \\
\hline RED BLOOD CELL VOLLME & . & 38.8 per cent. \\
\hline RETICLLOCYTES ～. & & 0.8 per cent. \\
\hline NON-PROTEIN NITROGEN & . & $58.8 \mathrm{mgm}$. per cent. \\
\hline SERLM PROTEIN ～. & . & 5.90 gm. per cent. \\
\hline BLOOD PRESSLRE & . & $124 / 68 \mathrm{~mm} . \mathrm{Hg}$. \\
\hline
\end{tabular}


Urine contained albumin and blood as before; its volume was approximately 1020 c.c.

J. C. Male, aged 5 years. Admitted 29.4.38, discharged 29.9.38.

History. Swelling of abdomen for two years. Frequent attacks of tonsillitis. On 15.4.38 the urine was noted to be dark red and two days before admission the child became ill and out of sorts.

ON ADMISSION. Slight oedema was found which gradually improved; there was moderate ascites. When first investigated on 19.7.38 the blood and urine examination gave the following results :

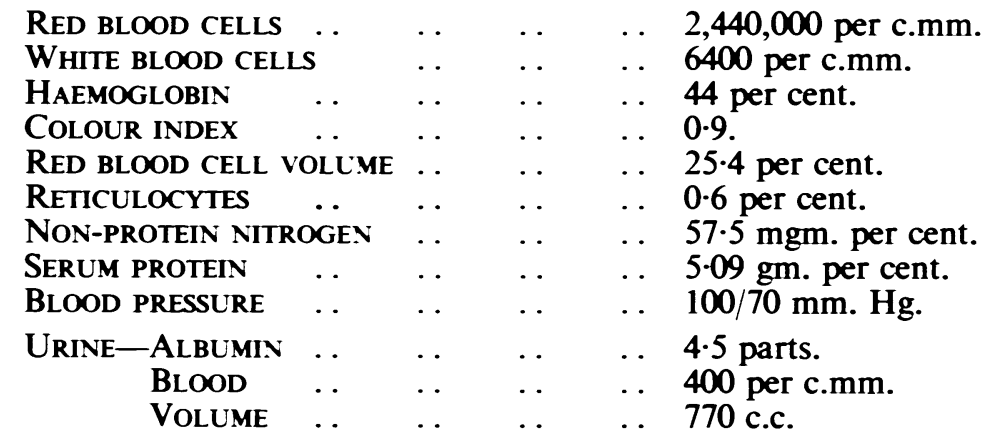

Oedema disappeared, but ascites and haematuria persisted and his general condition had not improved on transfer to another hospital on September 29, 1938. On 30.8.38 the blood and urine examination gave the following results:

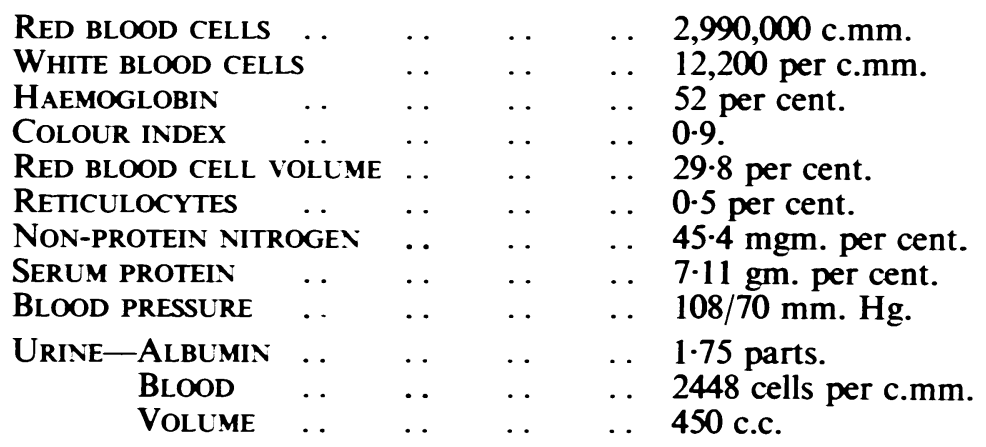

A. A. Female, aged 8 years. Admitted 22.10.37, discharged 30.6.38.

Scarlet fever and ill for six months at age of seven years. In April, 1937, her face became puffy and later legs and arms. Five weeks before admission she had a febrile illness and swelling became more marked.

ON ADMISsion. Well-marked oedema and moderate haematuria were present. The state of the blood and urine was as follows:

\begin{tabular}{|c|c|c|c|}
\hline RED BLOOD CELLS & & .. & $3,625,000$ per c.mm. \\
\hline WHITE BLOOD CELLS & $\cdots$ & . & 13,600 per c.mm \\
\hline HAEMOGLOBIN . & & & 68 per cent. \\
\hline COLOUR INDEX & . & .. & 0.9 \\
\hline RED BLOOD CELL VOLLME & . & & $29 \cdot 0$ per cent. \\
\hline RETICULOCYTES ～. . & . & . & $1 \cdot 1$ per cent. \\
\hline NON-PROTEIN NITROGEN & . & . & $28.7 \mathrm{mgm}$. per cent. \\
\hline SERUM PROTEIN $\quad \ldots$ & . & . & 5.25 gm. per cent. \\
\hline BLOOD PRESSLRE & & . & 124/78 mm. Hg. \\
\hline
\end{tabular}




$\begin{array}{cccccl}\text { URINE-ALBUMIN } & \ldots & \ldots & \ldots & \ldots & 2.0 \text { parts. } \\ \text { BLOOD } & \ldots & \ldots & \ldots & \ldots & 691 \text { cells per c.mm. } \\ \text { VOLUME } & \ldots & \ldots & \ldots & \ldots & 520 \text { c.c. }\end{array}$

Oedema slowly disappeared only to come and go later and the general condition remained more or less stationary. In spite of haematinic therapy the following figures show that on 16.6.38 the condition of the blood had deteriorated.

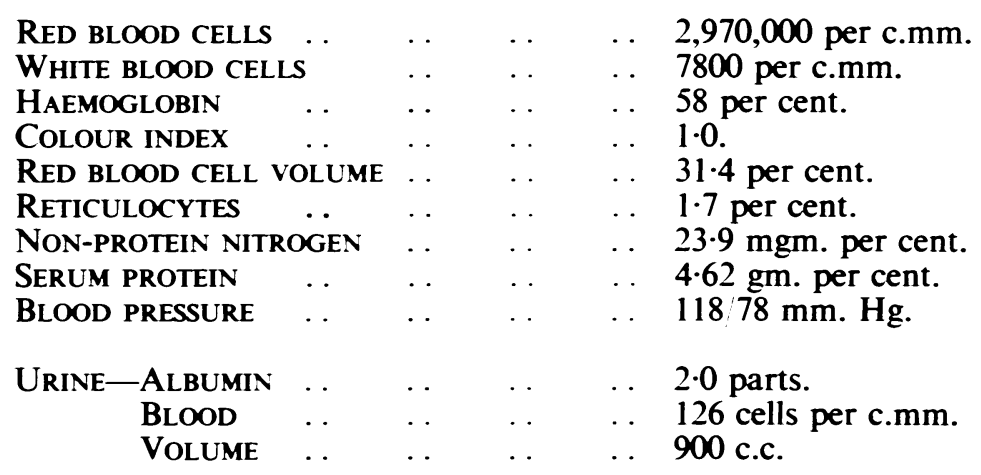

J.S. Male, aged 9 years. Admitted 28.7.37, discharged 17.1.38.

Two weeks before admission his face became puffy and he complained of anorexia and listlessness. One week before admission oedema became widespread and severe.

ON ADMISSION. There was general anasarca and ascites, and much blood and albumin in urine. His blood pressure was not raised. Non-protein nitrogen was $39 \mathrm{mgm}$. per cent. Serum protein was $5.45 \mathrm{gm}$. per cent. In August an effusion developed in both pleura. During September and October the oedema and ascites increased greatly, but at the end of October gradually began to subside. Special examination of the blood began on October 18, when the following findings were recorded:

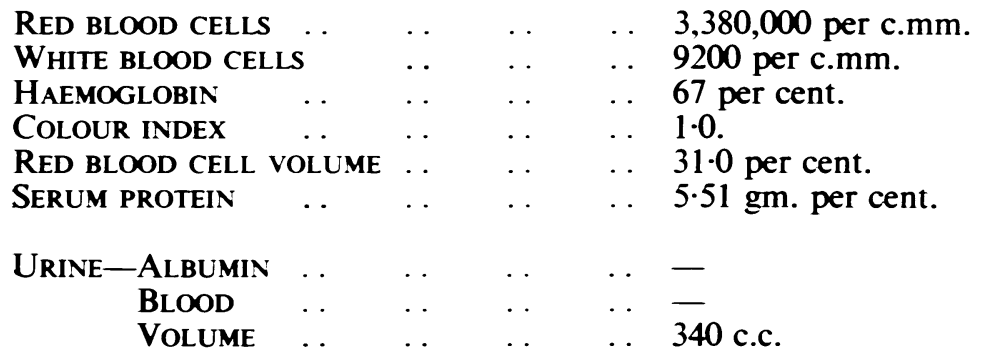

By December the oedema and ascites had disappeared and the urine had become free from blood. Examination of the blood and urine on 9.12.37 gave the following results:

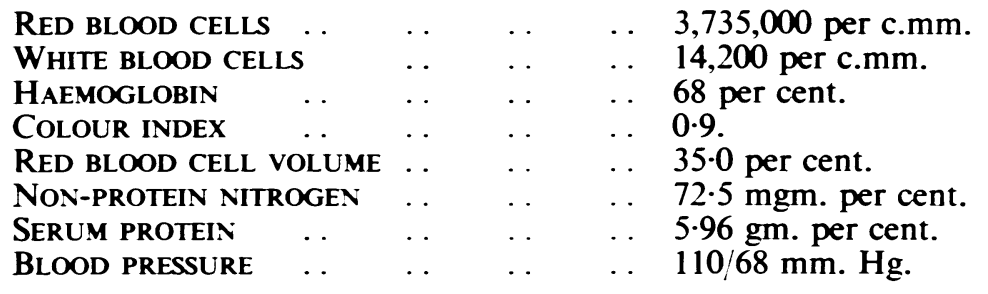




$\begin{array}{cccccl}\text { URINE-ALBUMIN } & \ldots & \ldots & \ldots & \ldots & 4 \text { parts. } \\ \text { BLOOD } & \ldots & \ldots & \ldots & \ldots & \text { Nil. } \\ \text { VOLUME } & \ldots & \ldots & \ldots & \ldots & 1200 \text { c.c. }\end{array}$

It is in this group, and in this group only, that the characteristic anaemia of nephritis has been found to occur. The difference between the blood findings in this group shown in table 8 and those in the other groups (tables 2, 4 and 6) is striking. In this type of the disease there is a considerable anaemia with a slightly greater reduction in the haemoglobin percentage than in the number of red cells giving a colour index of $0 \cdot 9$. The mean corpuscular volume is 95 cubic microns indicating that the cells are of normal size or slightly larger than normal, a finding in agreement with that of Townsend, Massie and Lyons (1937). Observations made two to three months later (table 8) show practically no change in the state of the blood in spite of active treatment both with iron and liver. Thus in this group there is a moderately severe normocytic or megalocytic anaemia which may be described as orthochromic and which is not materially influenced by treatment.

TABLE 8

THE BLOOD IN CHRONIC HAEMORRHAGIC NEPHRITIS

\begin{tabular}{|c|c|c|c|c|c|c|c|c|c|}
\hline \multicolumn{5}{|c|}{ SOON AFTER ADMISSION TO HOSPITAL } & \multicolumn{5}{|c|}{2 TO 3 MONTHS AFTER ADMISSION TO HOSPITAL } \\
\hline NAME & $\begin{array}{c}\text { RED } \\
\text { CELLS } \\
\text { PER } \\
\text { C.MM. }\end{array}$ & $\begin{array}{l}\text { Hb. } \\
\text { PER } \\
\text { CENT. } \\
\text { (HAL- } \\
\text { DANE) }\end{array}$ & $\begin{array}{l}\text { WHITE } \\
\text { CELLS } \\
\text { PER } \\
\text { C.MM. }\end{array}$ & $\begin{array}{l}\text { R.B.C. } \\
\text { VOL. } \\
\text { PER } \\
\text { CENT. }\end{array}$ & NAME & $\begin{array}{c}\text { RED } \\
\text { CELLS } \\
\text { PER } \\
\text { C.MM. }\end{array}$ & \begin{tabular}{|l} 
Hb. \\
PER \\
CENT. \\
(HAL- \\
DANE)
\end{tabular} & $\begin{array}{l}\text { WHITE } \\
\text { CELLS } \\
\text { PER } \\
\text { C.MM. }\end{array}$ & $\begin{array}{l}\text { R.B.C. } \\
\text { VOL. } \\
\text { PER } \\
\text { CENT. }\end{array}$ \\
\hline 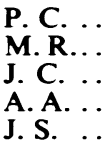 & $\begin{array}{l}4,035,000 \\
2,190,000 \\
2,440,000 \\
3,625,000 \\
3,735,000\end{array}$ & $\begin{array}{l}70 \\
42 \\
44 \\
68 \\
68\end{array}$ & $\begin{array}{r}11,400 \\
11,100 \\
6,400 \\
13,600 \\
14,200\end{array}$ & $\begin{array}{l}36 \cdot 4 \\
25 \cdot 0 \\
25 \cdot 4 \\
29 \cdot 0 \\
35 \cdot 0\end{array}$ & $\begin{array}{l}\text { P. C. } \\
\text { M. R. } \\
\text { J. C. } \\
\text { A. A. } \\
\text { J. S. } \quad \text {. }\end{array}$ & $\begin{array}{l}3,985,000 \\
2,540,000 \\
2,990,000 \\
3,000,000 \\
\text { Dismissed }\end{array}$ & $\begin{array}{r}76 \\
50 \\
52 \\
60 \\
\text { from }\end{array}$ & $\begin{array}{c}12,400 \\
11,700 \\
12,200 \\
8,300 \\
\text { hospital }\end{array}$ & $\begin{array}{l}38 \cdot 2 \\
28 \cdot 6 \\
29 \cdot 8 \\
30 \cdot 0\end{array}$ \\
\hline Average & $3,205,000$ & 58 & 11,320 & $30 \cdot 2$ & Average & $3,129,000$ & 59 & 11,500 & $31 \cdot 6$ \\
\hline
\end{tabular}

Average colour index, 0.90.

Average colour index, 0.94.

Average mean corpuscular volume, 94 c. Average mean corpuscular volume, $101 \mathrm{c}$. microns. microns.

From table 8 it will be seen that there was a moderate leucocytosis. Films showed the red cells to be well coloured and fairly uniform in size. The differential counts on four of these children are recorded in table 9. No abnormal red or white cells were seen. All the children showed some degree of lymphocytosis and one of them had an eosinophilia of 3.5 per cent. The number of reticulocytes was variable, but never amounted to less than 0.5 per cent. of the red cells. It is interesting to note that these children had a moderate leucocytosis and a normal or increased reticulocyte count, whereas idiopathic aplastic anaemia, with which this disease is so often compared, is associated with leucopenia and the absence of reticulocytes. 
TABLE 9

DIFFERENTIAL COUNTS OF NUCLEATED CELLS IN A GROUP OF CHILDREN WITH CHRONIC HAEMORRHAGIC NEPHRITIS

\begin{tabular}{|c|c|c|c|c|c|c|c|c|c|}
\hline \multirow{2}{*}{ NAME } & \multirow{2}{*}{$\begin{array}{l}\text { NEUTRO- } \\
\text { PHIL } \\
\text { POLY- } \\
\text { MORPHS }\end{array}$} & \multirow{2}{*}{$\begin{array}{c}\text { BASO- } \\
\text { PHIL } \\
\text { POLY- } \\
\text { MORPHS }\end{array}$} & \multirow{2}{*}{$\begin{array}{l}\text { EOSINO- } \\
\text { PHIL } \\
\text { POLY- } \\
\text { MORPHS }\end{array}$} & \multirow{2}{*}{$\begin{array}{l}\text { META- } \\
\text { MYELO- } \\
\text { CYTES }\end{array}$} & \multirow{2}{*}{$\begin{array}{l}\text { LYMPHO- } \\
\text { CYTES }\end{array}$} & \multirow{2}{*}{$\begin{array}{l}\text { NORMO- } \\
\text { BLASTS }\end{array}$} & \multirow{2}{*}{$\begin{array}{c}\text { MYELO- } \\
\text { CYTES }\end{array}$} & \multicolumn{2}{|c|}{ RETICULOCYTES } \\
\hline & & & & & & & & HIGHEST & LOWEST \\
\hline $\begin{array}{l}\text { P. C. } \\
\text { M. R. } \\
\text { J. C. } \\
\text { A. A. }\end{array}$ & $\begin{array}{l}47 \\
46 \\
60 \\
46\end{array}$ & $\begin{array}{l}0 \\
0 \cdot 5 \\
0 \\
0.5\end{array}$ & $\begin{array}{l}1.0 \\
0.5 \\
0 \\
3.5\end{array}$ & $\begin{array}{l}9 \\
3 \\
2 \\
5\end{array}$ & $\begin{array}{l}43 \\
50 \\
38 \\
45\end{array}$ & $\begin{array}{l}\mathbf{0} \\
\mathbf{0} \\
\mathbf{0} \\
\mathbf{0}\end{array}$ & $\begin{array}{l}\mathbf{0} \\
\mathbf{0} \\
\mathbf{0} \\
\mathbf{0}\end{array}$ & $\begin{array}{r}3 \cdot 1 \\
14.0 \\
0.6 \\
2.6\end{array}$ & $\begin{array}{l}0.8 \\
0.5 \\
0.5 \\
0.6\end{array}$ \\
\hline
\end{tabular}

Figures are per cent. of all white cells except reticulocytes which are per cent. red cells.

\section{Discussion}

The results appear to show that both in the nephrotic syndrome and in acute haemorrhagic nephritis there are definite changes in the concentration of certain constituents of the blood, but that there is no evidence that either disease produces any absolute diminution in the number of red cells or in the haemoglobin content. In nephrosis the concentration reaches its height during the period of oliguria and when oedema is pronounced, whereas in acute haemorrhagic nephritis it reaches its maximum during active diuresis and when oedema is subsiding. As a possible explanation of these paradoxical reactions it may be suggested that in nephrosis the secretory power of the kidney is not impaired but that blood concentration is brought about by leak of fluid from the vascular system into the tissues producing oedema. Whether this is due to increased permeability of endothelial tissue or solely to alterations in osmotic pressure it is impossible to say. In acute nephritis, on the other hand, the excretory power of the kidney is impaired, but blood dilution is prevented by passage of excess fluid into the tissues. When diuresis begins in this type of the disease haemoconcentration occurs because fluid is withdrawn from the vascular system by the kidneys more quickly than it can be replenished from the oedematous tissues.

It is important to bear in mind these fluctuations in the red cell counts and haemoglobin percentage before deciding on the presence or absence of anaemia and the efficacy of the treatment of the anaemia. In the nephrotic syndrome any anaemia that may be present will be masked during increasing oedema by haemocc ncentration, and the true state of the blood will only become manifest during a non-oedematous phase. On the other hand, in acute nephritis serial counts done when the patient is recovering and when the first flood of diuresis has ceased will reveal what appears to be an increasing anaemia, but is in reality only a diminishing hemoconcentration. Not until four or five weeks after oedema has disappeared does the red cell count reflect the true state of the blood. Any further reduction after this would indicate a true progressive anaemia. 
Contrary to the findings of other workers this investigation has failed to demonstrate anaemia in nephrosclerosis in the absence of such complicating factors as haemorrhage.

It seems that only in chronic haemorrhagic nephritis is there true anaemia. It is orthochromic and normocytic. Its cause is difficult to explain. It might be suggested that the anaemia in this type of nephritis is due to loss of blood through the kidney, but this is improbable as the amount of blood lost is extremely small and chronic haemorrhage should lead to anaemia of the hypochromic type. The fact that treatment with iron is of no avail provides additional evidence that it is not due to blood loss. Furthermore, it does not appear to be due to marrow aplasia for there is no diminution in the number of white cells and reticulocyte counts are within normal limits.

\section{Conclusions}

(1) Previous work on anaemia in nephritis is discussed.

(2) In oedematous patients blood obtained by puncture of the lobe of the ear is slightly diluted, but the errors arising in doing counts from blood obtained by vene-puncture are greater than those arising from skin puncture, and the latter method is therefore preferable.

(3) During the stage of increasing oedema and oliguria in nephrosis and during the stage of diminishing oedema and active diuresis in acute nephritis there is blood concentration. In neither of these types of nephritis is there more than slight anaemia.

(4) When certain acute infections occur in the course of nephrosis rapid and severe anaemia results and after effective treatment of the infection the blood quickly returns to normal.

(5) Anaemia is not characteristic of nephrosclerosis in the absence of haemorrhage, and when this occurs there is evidence of active haemopoiesis.

(6) In chronic haemorrhagic nephritis there is often severe orthochromic normocytic anaemia with a normal or slightly increased number of reticulocytes and mild leucocytosis. The blood picture is not that of aplastic anaemia. No treatment that will influence the condition is known. It is only in this type of nephritis that true anaemia has been found.

Thanks are due to Professor G. Fleming, Dr. Stanley Graham and to other members of the clinical and laboratory staff for much valuable help. The work was carried out during the tenure of a McCunn Scholarship and part of the expenses were defrayed by the Medical Research Council.

\section{REFERENCES}

Berg, B. (1921). Med. Rec., 100, 914. (Quoted Parsons and Ekola-Strolberg.)

Brown, G. E., and Roth, G. (1922). Arch. intern. Med., 30, 817.

Cass, J. M. (1939). Arch. Dis. Childh., 14, 137.

Ceconi, A. (1905). Clin. med. ital., 44, 15.

Graff, S., and Clarke, H. T. (1931). Arch. intern. Med., 48, 808. 
Grawitz, E. (1911). Klinische Pathologie des Blutes, 4th ed., Leipzig, p. 877.

Hooper, C. W., Smith, H. P., Belt, A. E., and Whipple, G. H. (1920). Amer. J. Physiol., 51, 205.

McClure, W. B., de Takáts, C. B., and Hinman, W. F. (1933). Arch. intern. Med., $51,819$.

Murphy, F. D., Grill, J., and Moxon, G. F. (1934). Ibid., 54, 483.

Parsons, L., and Ekola-Strolberg, M. (1933). Amer. J. med. Sci., 185, 181.

Thursfield, H. (1934). Diseases of Children, edited by Garrod, A., Batten, F. E., and Thursfield, H., 3rd ed., London, p. 485.

Townsend, S. R., Massie, E., and Lyons, R. H. (1937). Amer. J. med. Sci., 194, 637.

Van Slyke, D. D., et al. (1930). Medicine, 9, 257.

Wintrobe, M. M. (1934). Arch. intern. Med., 54, 256. 